\title{
PENGENALAN APBN, NILAI KEMENTERIAN KEUANGAN DAN PENINGKATAN MOTIVASI: KEMENKEU MENGAJAR 3 DI SD NEGERI TOMANG 11 PAGI, JAKARTA BARAT
}

\author{
Akhmad Solikin \\ Jurusan Akuntansi, Politeknik Keuangan Negara STAN \\ akhsol@pknstan.ac.id
}

\begin{abstract}
ABSTRAK
Kementerian Keuangan sebagai lembaga pemerintah perlu memperkenalkan organisasi kepada masyarakat, termasuk kepada siswa sekolah dasar. Salah satu kegiatan yang dilakukan dalam rangka hari ulang tahun Kementerian Keuangan tahun 2018 adalah relawan mengajar dari pejabat dan pelaksana Kementerian Keuangan. Kegiatan ini bertujuan untuk meningkatkan pemahaman siswa tentang APBN, nilai-nilai Kementerian Keuangan serta meningkatkan motivasi siswa, yang dalam artikel ini berfokus pada SD Negeri Tomang 11 Pagi, Jakarta Barat. Metode yang pelaksanaan pada pengabdian masyarakat tersebut adalah metode tatap muka dengan menggunakan alat peraga, cerita dan permainan. Alat peraga untuk menjelaskan APBN dengan membandingkan anggaran rumah tangga dengan anggaran negara, untuk menjelaskan nilai-nilai Kementerian Keuangan digunakan tebak gambar dan kata serta cerita, sedangkan penggalian cita-cita dan motivasi dilakukan dengan permainan dan pohon cita-cita. Berdasarkan hasil observasi terhadap siswa dan evaluasi terhadap guru dan relawan disimpulkan bahwa rangkaian sesi inspirasi dalam kegiatan ini meningkatkan pengetahuan siswa terhadap penerimaan dan belanja negara, nilai-nilai Kementerian Keuangan serta motivasi siswa untuk melanjutkan pendidikan ke jenjang lebih tinggi dalam rangka mencapai cita-cita mereka.
\end{abstract}

Kata Kunci: anggaran negara, alat peraga pengajaran, nilai-nilai Kementerian Keuangan, motivasi belajar siswa

\begin{abstract}
Ministry of Finance as a government unit needs to inform its organisations to the general public, including elementary school students. One of activities during Ministry of Finance's anniversary 2018 was voluntary teachings from offocials and staffs of Ministry of Finance. The activity aimed at increasing students' awareness toward state budget, Ministry of Finance values, and motivating students, in this article epscially focuses on SD Negeri Tomang 11 Pagi, Jakarta Barat. Methods used in this community engagement were face to face teaching using teaching aids, stories, and games. Teaching aids to explain state budget was comparison between household budget and state budget, to describe Ministry of Finance values were picture and words puzzles and stories, while to explore future aspiration was using games and an aspiration tree. Based on observation on students and evaluation with teachers and volunteers it was concluded that inspiration sessions improved students' consciousness on state budget, Ministry of Finance values, and motivated students to continue their education to the higher level for achieving their dreams.
\end{abstract}

Keywords: state budget, teaching aids, Ministry of Finance values, student learning motivation

\section{A. PENDAHULUAN}

Berdasarkan Undang-Undang Dasar Negara Republik Indonesia tahun 1945 pasal 31 ayat 1, bahwa pendidikan merupakan hak setiap warga negara. Lebih lanjut dalam ayat 2 ditegaskan bahwa setiap warga negara wajib mengikuti pendidikan dasar dan pemerintah menyediakan dana untuk membiayai pendidikan dasar tersebut. Pada 
kenyataannya, terdapat masyarakat yang kurang beruntung mendapatkan pendidikan menengah. Terdapat banyak kurang beruntung siswa yang tidak melanjutkan pendidikan dari pendidikan dasar ke pendidikan menengah serta dari pendidikan menengah ke pendidikan tinggi (OECD/ADB, 2015).

Salah satu sekolah dasar yang menghadapi masalah dalam memotivasi siswanya untuk melanjutkan pendidikan ke jenjang yang lebih tinggi adalah Sekolah Dasar Negeri Tomang 11 Pagi yang berada di Jakarta Barat. Sekolah tersebut sebanarnya termasuk sekolah yang berprestasi dengan memperoleh gelar Adiwiyata. Berdasarkan sistem zonasi (Safarah \& Wibowo, 2018), sekolah diwajibkan memprioritaskan calon siswa yang berasal dari lokasi yang terdekat dengan sekolah. Akibat kebijakan tersebut, sekolah mempunyai banyak murid yang berasal dari keluarga yang kurang beruntung dari segi ekonomi. Banyak murid merupakan keluarga pemulung yang tinggal pada rumah-rumah sempit di sekitar rel kereta api dan saluran air. Dengan latar belakang sosial dan ekonomi tersebut, banyak siswa yang memenuhi keinginan orang tua untuk membantu mencari nafkah dan tidak melanjutkan pendidikan pada jenjang pendidikan sekolah menengah pertama (SMP).

Di lain pihak, sebagai Kementerian Keuangan sebagai sebuah institusi perlu memperkenalkan tugas pokok dan fungsinya kepada masyarakat, termasuk kepada siswa sekolah dasar. Komunikasi dan etika dalam pelayanan masyarat perlu dilakukan pemerintah untuk menjaga hubungan harmonis dengan masyarakat dalam rangka meningkatkan pelayanan publik (Aminulloh, Setyawan, \& Fauzan, 2014). Komunikasi bisa dilakukan dengan media digital, misalnya komunikasi online (Azhary \& Kriyantono, 2018) maupun komunikasi secara tatap muka. Salah satu kegiatan yang dilakukan untuk memperkenalkan Kementerian Keuangan kepada siswa sekolah dasar adalah kegiatan Kementerian Keuangan Mengajar. Kemenkeu Mengajar merupakan kegiatan unik dari suatu kementerian atau lembaga dalam kegiatan kerelawanan atau pengabdian masyarakat, yang diselenggarakan berkaitan dengan ulang tahun Kementerian Keuangan (Hari Oeang).

Tulisan tentang pengabdian masyarakat pada lembaga pendidikan relatif banyak dilakukan. Sebagai contoh, Fachriyah dan Safaah (2018) melakukan kursus singkat Bahasa Inggris kepada anak-anak usia sekolah dasar di suatu perumahan di Serang, sedangkan Widiyarto, Mubasyira, dan Ati (2018) mengadakan pelatihan keterampilan komunikasi Bahasa Inggris pada siswa suatu SMP di Kota Bekasi. Oktavianti dan Loisa 
(2017) melakukan penyuluhan tentang penggunaan media sosial pada siswa sebuah SMA di Jakarta Barat. Rahman dan Perdana (2019) memberikan penyuluhan Sistem Manajemen Kesehatan dan Keselamatan Kerja (SMK3) pada dua SMK di Cilegon. Selain itu, Wahyuni, Rachman, dan Hendrawan (2016) melaksanakan pelatihan pemrograman kepada siswa terpilih dan guru pada tiga SMA di Kabupaten Bangkalan.

Meskipun demikian, sepanjang pengetahuan penulis belum terdapat kegiatan pengabdian masyarakat yang secara khusus diinisiasi oleh kementerian/lembaga pemerintah, diikuti oleh staf dan pejabat kementerian tersebut, serta menjelaskan topik tentang Anggaran Pendapatan dan Belanja Negara (APBN). Artikel ini diharapkan dapat memberikan gambaran lengkap tentang kegiatan tersebut. Dengan demikian, tujuan untuk memperkenalkan tugas pokok dan fungsi Kementerian Keuangan lebih berjangkauan luas. Selain itu, kegiatan Kemenkeu Mengajar, khususnya yang dibahas dalam ini kegiatan yang berlokasi di Sekolah Dasar Negeri Tomang 11 Pagi diharapkan dapat (1) meningkatkan pengetahuan siswa tentang APBN, tugas pokok dan fungsi serta nilai-nilai Kementerian Keuangan dan (2) mengidentifikasi cita-cita masing-masing serta memupuk semangat siswa untuk mencapai cita-cita dengan meneruskan pendidikan ke tingkat yang lebih tinggi. Dalam kaitan dengan tujuan kedua, kegiatan ini berusaha meyakinkan kepada siswa tentang peran negara untuk membantu siswa mencapai cita-citanya dengan menyediakan pendanaan pendidikan pada tingkat pendidikan dasar dan menengah.

\section{B. LANDASAN TEORI}

\section{Peran APBN dalam Pendidikan}

APBN mempunyai fungsi alokasi, fungsi distribusi, dan fungsi stabilisasi (Dit. Penyusunan APBN, 2014). Peran alokasi dilakukan dengan mengalokasikan sumber daya ekonomi agar efisien, peran distribusi terkait dengan redistribusi sumber daya ekonomi kepada pihak yang membutuhkan, sedangkan peran stabilisasi untuk menjaga kondisi ekonomi tetap stabil dengan pertumbuhan yang tinggi dan pengangguran yang rendah.

Menurut Hipotesis Keynes, pengeluaran pemerintah dalam APBN dapat dipergunakan untuk meningkatkan perekonomian (Solikin, 2018). Selain sebagai alat untuk memengaruhi perekonomian, pengeluaran pemerintah dalam APBN dapat dipergunakan untuk mengatasi eksternalitas negatif (misalnya untuk mengatasi 
pencemaran lingkungan) dan mendorong pengembangan eksternalitas positif (misalnya untuk membiaya pendidikan dasar). Dalam hal ini, pendidikan terutama pendidikan dasar memberikan eksternalitas positif karena warga negara yang berkualitas umumnya mempunyai sifat dan perilaku yang baik. Sebagai misal, orang yang berpendidikan baik diharapkan patuh pada peraturan, kurang terlibat pada tindakan kejahatan serta mempunyai produktivitas tinggi. Apabila penyediaan barang publik berupa pendidikan diserahkan kepada pihak swasta, maka akan terjadi penyediaan yang kurang optimal (Gruber, 2012). Dengan demikian, peran negara diperlukan untuk menyediakan pendanaan atau secara langsung menyelenggarakan pendidikan, khususnya pendidikan dasar dan menengah.

Berdasarkan UUD 1945, dana pendidikan wajib dianggarkan minimal 20 persen dari pengeluaran. Pemenuhan angka 20 persen tersebut terdiri dari belanja pemerintah pusat, transfer ke daerah dan dana desa serta lewat pembiayaan pendidikan. Menurut Nota Keuangan dan APBN 2019, khusus untuk anggaran pendidikan lewat belanja pemerintah pusat dalam APBN 2018 dianggarkan sebesar Rp149,7 triliun, yang naik menjadi sebesar Rp163,1 triliun dalam APBN 2019. Program yang didanai misalnya adalah Program Indonesia Pintar untuk 20,1 juta siswa dan Bantuan Operasional Sekolah (BOS) untuk 55,8 juta siswa.

\section{Motivasi Berprestasi}

Menurut teori motivasi tiga kebutuhan (three needs theory) yang dikembangkan oleh McClelland dan kawan-kawan, terdapat tiga sumber motivasi yaitu kebutuhan untuk pencapaian (need for achievement, nAch), kebutuhan untuk berkuasa (need for power, nPow), dan kebutuhan untuk berafiliasi (need for affilitiation, nAff) (Robbins \& Coulter, 2018). Orang atau siswa dengan dorongan nAch yang tinggi cenderung untuk berprestasi yang tinggi semata-mata bukan karena imbalan, tetapi karena ingin berprestasi yang lebih baik daripada prestasi sebelumnya. Dalam hal ini, apabila siswa dapat dimotivasi untuk mempunyai nAch yang tinggi, diharapkan akan mempunyai motivasi yang tinggi sehingga di masa mendatang dapat mencapai cita-citanya.

Penelitian Saputra dan Muhari (2014) menunjukkan bahwa terdapat hubungan antara cita-cita dengan motivasi berprestasi siswa. Artinya bahwa siswa dengan citacita yang tinggi mempunyai motivasi berprestasi yang tinggi. Dengan demikian, pemberian motivasi kepada siswa-siswi sekolah dasar untuk mencapai cita-citanya di 
tengah kondisi kekurangan ekonomi diharapkan dapat meningkatkan motivasi mereka untuk berprestasi.

\section{METODE PELAKSANAAN}

Kegiatan Kemenkeu Mengajar 3 dilaksanakan pada 22 Oktober 2018 sebagai rangkaian dari Hari Ulang Tahun Kementerian Keuangan (Hari Oeang) ke-72 tahun 2018. Kegiatan dilaksanakan di 34 propinsi, 67 kabupaten/kota, pada 174 sekolah dasar yang meliputi 58.799 siswa, yang melibatkan 3.562 relawan panitia, relawan pengajar dan relawan dokumentasi dari pejabat dan pelaksana Kementerian Keuangan (Kemenkeu, 2018). Karya tulis ini khusus melaporkan kegiatan penulis dan relawan pengajar lain pada Kemenkeu Mengajar 3 yang diselenggarakan di SD Negeri Tomang 11 Pagi, Jakarta Barat.

\section{Persiapan}

Sebelum bertugas, para relawan dikumpulkan untuk mendapatkan pengarahan. Untuk panitia daerah Jakarta, briefing dilakukan di Kantor Pusat Kementerian Keuangan, Jalan Dr. Wahidin, Jakarta Pusat pada tanggal 21 September 2018. Selain itu, panitia per lokasi juga melakukan persiapan tersendiri dalam bentuk pertemuan baik secara tatap muka mupun dengan daring. Persiapan tatap muka meliputi pertemuan dengan kepala sekolah dan guru di sekolah lokasi kegiatan, dan pertemuan panitia yang membahas mengenai topik dan bentuk pengajaran serta persiapan alat-alat peraga pendidikan. Kelompok relawan yang bertugas di SD Negeri Tomang 11 diberikan nama Kelompok Samsi Sastrawidagda, merujuk pada tokoh Menteri Keuangan pada Kabinet RI pertama (Media Keuangan, 2017).

Sekolah Dasar Negeri Tomang 11 Pagi berlokasi di Jalan Rawa Kepa VII No. 12, RT 09/RW 15, Tomang, Grogol Petamburan, RT 8/RW 12, Tomang, Kecamatan Grogol Petamburan, Kota Jakarta Barat, Daerah Khusus Ibukota Jakarta, Kode Pos 11440. Menurut Data Pokok Pendidikan Dasar dan Menengah, Ditjen Pendidikan Dasar dan Menengah, SD tersebut mempunyai akreditasi A dengan lima belas (15) rombongan belajar. Khusus kelas besar terdiri dari Kelas 4 (3 rombongan belajar), Kelas 5 (2 rombongan belajar) dan Kelas 6 (3 rombongan belajar). Mengingat keterbatasan relawan pengajar, dalam kegiatan ini, metode pelaksanaan kegiatan dibedakan antara kelas besar dan kelas kecil, sebagaimana dipaparkan pada bagian berikut.

\section{Bentuk Pengajaran}


Pengajaran dilakukan dengan interaktif, dengan bantuan alat peraga. Berhubung hanya tersedia dua infocus, maka proses pengajaran dilakukan dengan alat papan tulis dan alat peraga. Alat peraga yang dipersiapkan meliputi topi kertas dan slot untuk menulis nama siswa/pengajar; berbagai tepuk, tari dan lagu; tabel perbandingan keuangan rumah tangga dan negara; potongan gambar-gambar yang terkait dengan fungsi keuangan rumah tangga dan negara; gambar-gambar dan tebak kata terkait dengan nilai-nilai Kementerian Keuangan; potongan kertas untuk menulis cita-cita; botol untuk menyimpan catatan cita-cita; dan pohon cita-cita. Dalam pengelolaan kelas, dipersiapkan juga mengenai pengelolaan secara nonfisik dalam bentuk kepedulian, ketegasan dan modeling dari pengajar (Isbadrianingtyas, Hasanah, \& Mudiono, 2016). Dua poin yang pertama terbukti sangat berguna dalam menghadapi siswa-siswi yang cenderung sangat aktif.

Kegiatan pengajaran dilakukan mulai dari upacara bendera sampai dengan waktu pulang pukul 11.30. Sebagaimana dicantumkan pada Tabel 1, kegiatan utama terdiri dari pengenalan Kementerian Keuangan dan APBN, pengenalan nilai-nilai Kementerian Keuangan, serta pengenalan ragam profesi, penggalian aspirasi profesi siswa, dan motivasi siswa untuk mencapai cita-citanya. Setiap pengajar/tim pengajar mengisi satu sesi pada suatu kelas kemudian berpindah ke kelas-kelas lainnya pada sesi-sesi berikutnya. Penggunaan sistem kelas berpindah diketahui dapat meningkatkan efektivitas pembelajaran di kelas (Hidayat, 2013). Khusus untuk kelas kecil (kelas 1, 2, dan 3) tidak mengikuti sesi-sesi inspirasi, setelah ice breaking mereka diajak berfoto dengan seragam Direktorat Jenderal Bea dan Cukai (sebagaimana diilustrasikan pada Gambar 1) dan kemudian kembali ke kelas untuk mengikuti kelas seperti biasa.

Tabel 1. Susunan Acara

\begin{tabular}{lll}
\hline Waktu & Kegiatan & Keterangan \\
\hline $06.00-06.30$ & Persiapan & Tiba di sekolah, briefing \\
06.30-07.00 & Upacara & Dipimpin relawan pengajar \\
07.00-07.10 & Ice breaking, moving & Tari prestasi, menuju kelas masing-masing \\
07.10-08.20 & Inspirasi sesi 1 & $\begin{array}{l}\text { Pengenalan Kementerian Keuangan dan } \\
\text { APBN }\end{array}$ \\
& & Nilai-nilai Kementerian Keuangan \\
$08.20-09.30$ & Inspirasi sesi 2 & Cita-citaku \\
$09.30-10.00$ & Istirahat & Ke lapangan, mengikat pohon cita-cita \\
10.00-11.10 & Insiprasi sesi 3 & \\
\hline
\end{tabular}

Sumber: Kelompok Samsi Sastrawidagda 


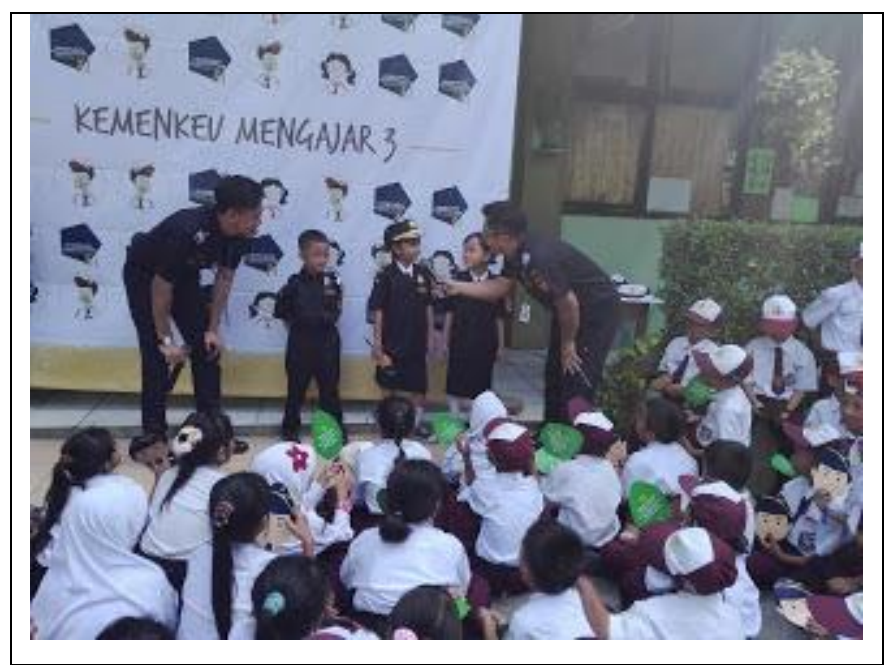

Gambar 1: Acara Kelas-Kelas Kecil

Sumber: SDN Tomang 11 Pagi (2018)

\section{Evaluasi}

Evaluasi dilakukan dengan observasi terhadap tanggapan dan perilaku siswa setelah kegiatan dilakukan. Setiap siswa yang aktif bertanya atau menjawab pertanyaan diberikan satu poin dalam bentuk stiker berwarna yang ditempelkan pada topi masing-masing. Secara umum, siswa antusias mengikuti kegiatan dan diharapkan lebih yakin dengan cita-citanya. Selain itu, evaluasi juga dilakukan dengan melakukan tatap muka dengan kepala sekolah dan guru. Pada tingkat lokal dan panitia daerah juga dilakukan refleksi dan evaluasi sekaligus penutupan purna tugas dengan menyelenggarakan pertemuan yang dihadiri oleh seluruh relawan daerah, panitia, dan perwakilan sekolah dan dinas pendidikan.

\section{HASIL DAN PEMBAHASAN}

Pada sesi 1, siswa diperkenalkan dengan Anggaran Pendapatan dan Belanja Negara (APBN) serta peran Kementerian Keuangan dalam pengelolaan keuangan negara. Pengenalan APBN dilakukan dengan mengilustrasikan negara seperti rumah tangga, sehingga dapat dimengerti siswa dengan lebih mudah. Pada konteks rumah tangga, pemimpinnya adalah ayah atau ibu, sedangkan dalam konteks pemerintah pemimpinnya adalah presiden. Untuk mengelola keuangan negara, terdapat lembaga negara dan pemerintahan yang berada di bawah pimpinan presiden. Salah satu kementerian tersebut adalah Kementerian Keuangan, yang bertugas untuk mengelola keuangan dan kekayaan negara.

Negara sebagaimana rumah tangga mempuyai sumber penerimaan dan pengeluaran. Penerimaan rumah tangga berasal dari hasil usaha orang tua, sedangkan penerimaan 
negara terutama diperoleh dari pajak. Pengeluaran rumah tangga digunakan untuk makanan, minuman, tempat tinggal, pakaian, dan sebagaimana. Di lain pihak, pengeluaran negara dikeluarkan untuk mendanai pendidikan, kesehatan, keamanan, dan penyediaan sarana umum. Selain itu, diperkenalkan bahwa rumah tangga dapat meminjam apabila pengeluaran lebih kecil daripada penerimaan. Dalam konteks negara, utang juga dapat dilakukan jika untuk kegiatan yang produktif.

Pengelolaan keuangan rumah tangga secara sederhana dilakukan dengan menyusun rencana, melakukan penerimaan dan pengeluaran serta melaksanakan pencatatan atau pembukuan. Khusus untuk keuangan negara, proses-proses tersebut dilakukan lewat proses terkait APBN. Hal-hal tersebut dijelaskan kepada siswa dengan menunjukkan perbandingan sederhana antara keluarga dan negara dalam mengelola keuangan sebagaimana ditunjukkan dalam Tabel 2. Siswa diminta secara aktif untuk mengidentifikasi isi dari setiap sel dengan memilih dan menempelkan gambar yang sesuai dengan kategori jawaban. Sebagai contoh, untuk memperkenalkan fungsi penyediaan pendidikan dalam APBN, siswa dapat memilih gambar "sekolah" untuk ditempelkan pada kolom negara dan baris kebutuhan pendidikan pada tabel alat peraga tersebut. Menurut penelitian (Hidayat, 2013), penggunaan alat peraga meningkatkan keingintahuan, rasa senang, perhatian dan tanggapan peserta didik terhadap pembelajaran. Ilustrasi proses belajar digambarkan pada Gambar 2.

Tabel 2. Penggunaan Dana Keluarga dan APBN

\begin{tabular}{lll}
\hline \multicolumn{1}{c}{ Pertanyaan } & \multicolumn{1}{c}{ Keluarga } & \multicolumn{1}{c}{ Negara } \\
\hline $\begin{array}{l}\text { Siapa yang mengatur } \\
\text { keuangan? }\end{array}$ & Ibu/Ayah & Menteri Keuangan \\
$\begin{array}{l}\text { Kebutuhan apa saja? } \\
\text { Pakaian, makanan, } \\
\text { mainan }\end{array}$ & $\begin{array}{l}\text { Jalan, jembatan, terminal, } \\
\text { pendidikan (sekolah), } \\
\text { listrik } \\
\text { Pendapatan dari }\end{array}$ & Bekerja \\
$\begin{array}{l}\text { mana? } \\
\text { Jika kebutuhan lebih } \\
\text { besar dari } \\
\text { pendapatan? }\end{array}$ & Utang & Utang \\
\hline
\end{tabular}

Sumber: Adaptasi dari Kelompok Samsi Sastrawidagda 


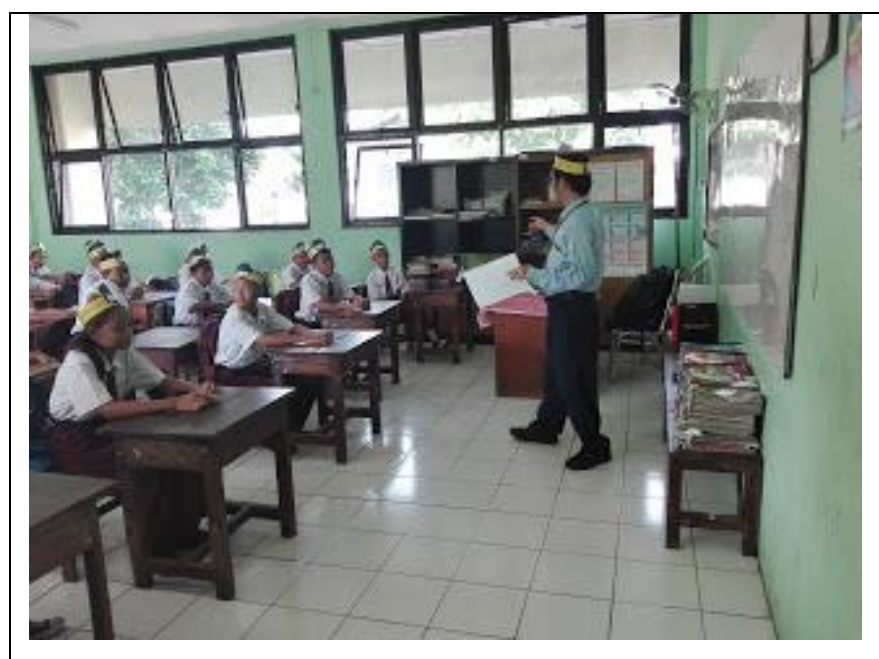

Gambar 2: Sesi Inspirasi di Salah Satu Kelas Sumber: SDN Tomang 11 Pagi (2018)

Pada sesi 2, pengenalan nilai-nilai Kementerian Keuangan dilakukan dalam bentuk gabungan antara tebak kata dan gambar yang melambangkan nilai tertentu. Setelah siswa berhasil menebak kata, relawan pengajar menjelaskan atau menceritakan pengertian, pentingnya dan kaitan nilai-nilai tersebut dengan tugas pokok dan fungsi Kementerian Keuangan. Menurut penelitian (Salim, Damajanti, \& Muljosumarto, 2018), penggunaan cerita dapat membantu untuk belajar mengenai nilai moral.

Nilai-nilai Kementerian Keuangan terdiri dari integritas, profesionalitas, sinergi, pelayanan, dan kesempurnaan (Susilo, 2016). Sebagai contoh, untuk menjelaskan mengenai nilai integritas, dipergunakan gambar seperti pada Gambar 3. Dalam konteks di sekolah, integritas atau kejujuran dapat diceritakan dalam perilaku yang tidak mencontek ketika ujian, sedangkan dalam konteks Kementerian Keuangan, nilai integritas diceritakan dalam kaitan dengan nilai anti korupsi.

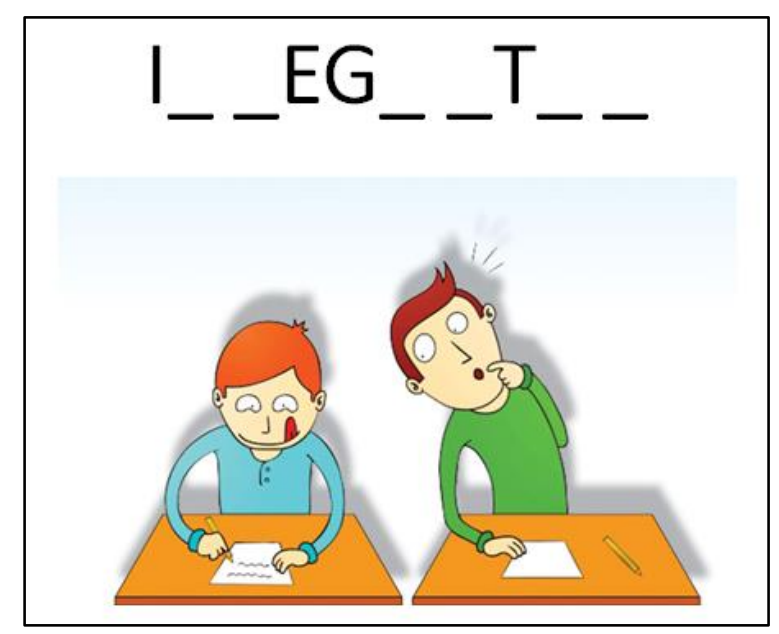

Gambar 3. Peraga Nilai Integritas

Sumber: Kelompok Relawan Kemenkeu Mengajar 3 SDN Pejaten Timur 15, Jakarta 
Pada sesi 3, setiap siswa diberikan satu potongan kertas berwarna untuk menuliskan cita-citanya. Sebelumnya, siswa diberikan gambaran mengenai profesi-profesi yang terdapat di masyarakat secara umum dan tugas-tugas tertentu yang terkait dengan fungsi Kementerian Keuangan. Sebagai contoh, relawan pengajar yang berasal dari Direktorat Jenderal Bea dan Cukai yang mengajar dengan seragam dapat menjelaskan mengenai tugasnya misalnya untuk menjaga perbatasan, mengawasi penumpang dan barang di bandar udara atau pelabuhan internasional, serta mencegah penyelundupan. Relawan pengajar juga dapat memberikan teka-teki pantomime, yaitu siswa atau pengajar menirukan tugas suatu profesi dalam bentuk gerakan-gerakan dan kemudian siswa menebak profesi tersebut. Penggunaan teknik pantomim tersebut menurut penelitian dapat meningkatkan kepercayaan diri (Fikri, Maulia, \& Hartini, 2016) dan kecerdasan kinestetik siswa (Fitria \& Yarshal, 2019).

Setelah siswa menuliskan cita-citanya, relawan pengajar menanyakan kepada setiap siswa yang bersedia bercerita mengenai cita-citanya. Selanjutnya, relawan pengajar menekankan bahwa semua profesi adalah baik dan mulia. Selain itu, siswa diberikan motivasi bahwa bahwa pencapaian cita-cita tersebut sangat tergantung dari keinginan siswa untuk belajar dan melanjutkan pendidikan ke tingkat yang lebih tinggi. Meskipun mempunyai kondisi ekonomi yang kurang beruntung, negara sangat berkeinginan agar warganya pintar dengan menyediakan pendanaan untuk pendidikan dalam APBN, sebagaimana telah dibahas pada sesi inspirasi sebelumnya.

Setelah itu, siswa memasukkan tulisan cita-cita dalam botol kecil. Botol-botol kecil tersebut kemudian diikat pada pohon tiruan yang digambarkan sebagai pohon cita-cita. Dengan memvisualisasikan dalam bentuk pohon, diharapkan siswa selalu teringat dengan cita-citanya dan termotivasi untuk mewujudkannya. Acara ditutup di lapangan sekolah dengan bernyanyi bersama, penyerahan penghargaan, dan foto bersama per kelas, sebagaimana diilustrasikan pada Gambar 4a dan 4b. 


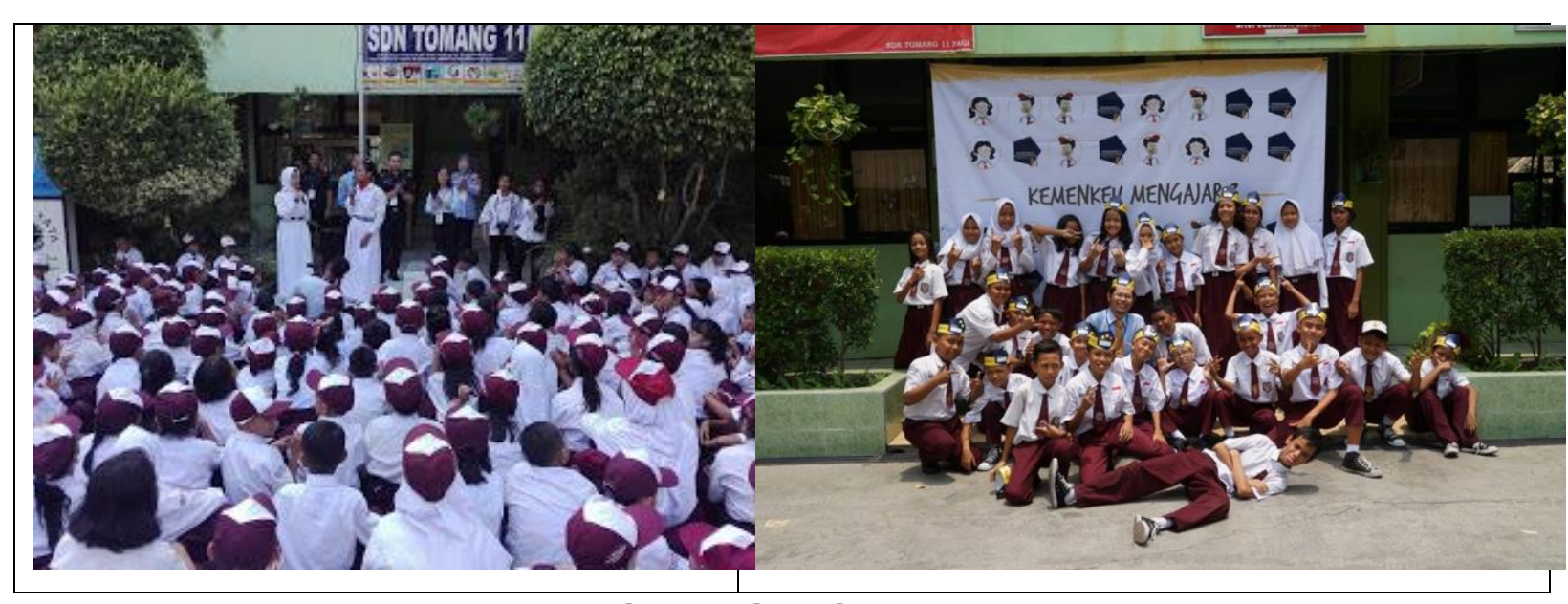

Gambar 4a dan 4b: Penutupan

Sumber: SDN Tomang 11 Pagi (2018); Tim Dokumentasi Kelompok Samsi

Sastrawidagda

\section{E. KESIMPULAN}

Berdasarkan hasil observasi terhadap respon siswa, pembicaraan dengan guru, dan evaluasi dan refleksi panitia, relawan pengajar, serta relawan dokumentasi bahwa kegiatan pengabdian masyarakat dalam bentuk Kemenkeu Mengajar 3 di SD Negeri Tomang 11 Pagi telah mencapai tujuannya. Siswa meningkat pemahamannya terhadap APBN dan nilai-nilai Kementerian Keuangan serta berhasil mengidentifikasi cita-cita masing-masing. Pemberian semangat dan pengertian mengenai peran APBN dalam membantu pendanaan pendidikan bagi siswa kurang mampu semoga dapat meningkatkan jumlah siswa yang melanjutkan pendidikan ke jenjang yang lebih tinggi.

\section{F. UCAPAN TERIMA KASIH}

Terima kasih disampaikan kepada relawan Kemenkeu Mengajar 3 yang bertugas di SD Negeri Tomang 11 Pagi, yaitu kepada fasilitator (Endang Puspawati), rekan-rekan relawan pengajar (Ilham Zahroni, Ika Kardian Rahmatullah, Teguh Djatmiko, Vivin Lafianty, dan Wanda S) dan relawan dokumentator (Chairul Trisnadi, Faisal, Heni, dan Rizqi Syifa Fauziah).

\section{G. DAFTAR PUSTAKA}

Aminulloh, A., Setyawan, D., \& Fauzan, F. (2014). Model komunikasi, sifat arogansi dan etika komunikasi pemerintah menuju pelayanan publik prima. Jurnal Ilmu Komunikasi, 12(2), 98-108.

Azhary, S., \& Kriyantono, R. (2018). Pemahaman petugas humas badan publik terhadap 
transparansi dan akuntabilitas informasi dalam penerapan humas online. Jurnal Pekommas, 3(2), 213-220.

Dit. Penyusunan APBN. (2014). Dasar-Dasar Praktek Penyusunan APBN di Indonesia.

(Purwiyantoro \& K. W. D. Nugraha, Eds.) (2nd ed.). Jakarta: DJA Kemenkeu.

Fachriyah, E., \& Safaah, E. (2018). Pelatihan short course bahasa inggris bagi anak usia sekolah di Puri Anggrek Serang. In SEMBADHA2018: Seminar Hasil Pengabdian Kepada Masyarakat (pp. 61-66). Jakarta: PKN STAN Press.

Fikri, R., Maulia, D., \& Hartini, T. (2016). Efektivitas layanan bimbingan kelompok dengan teknik pantomim untuk meningkatkan kepercayaan diri siswa SMK Negeri 1 Sayung. Empati: Jurnal Bimbingan Dan Konseling, 3(1), 1-10.

Fitria, D., \& Yarshal, D. (2019). Peningkatan kecerdasan kinestetik melalui kegiatan bermain pantomime di TKIT Madinah Lubuk Pakam. In Prosiding Seminar Nasional \& Exspo Hasil Penelitian dan Pengabdian Masyarakat 2019 (pp. 520-525). Medan: Universitas Muslim Nusantara Al Washliyah.

Gruber, J. (2012). Public Finance and Public Policy. New York: Worth Publishers. Hidayat, P. (2013). Alat peraga edukasi dan moving class dalam Pembelajaran di SD/MI. Didaktika: Jurnal Pembelajaran Ilmu Ke-SD-An, 4(1), 284-295.

Isbadrianingtyas, N., Hasanah, M., \& Mudiono, A. (2016). Pengelolaan kelas dalam pembelajaran tematik sekolah dasar. Jurnal Pendidikan: Teori, Penelitian, Dan Pengembangan, 1(5), 901-904.

Kemenkeu. (2018). Kemenkeu Mengajar. Retrieved June 11, 2019, from https://www.kemenkeu.go.id/publikasi/berita/menkeu-ikut-terjun-dalamkemenkeu-mengajar-3/

Media Keuangan. (2017, October). Kebijakan ekonomi keuangan periode 1945-2017, 12(121), 8-9.

OECD/ADB. (2015). Education in Indonesia: Rising to the Challenge. Paris: OECD Publishing.

Oktavianti, R., \& Loisa, R. (2017). Penggunaan media sosial sesuai nilai luhur budaya di kalangan siswa SMA. Jurnal Pengabdian Kepada Masyarakat, 3(1), 86-95. http://doi.org/10.22146/jpkm.26925

Rahman, A., \& Perdana, S. (2019). Pelatihan SMK3 kepada siswa SMKS Muhammadiyah Cilegon dan SMK Al-Insan Cilegon untuk menambah wawasan dan membantu menjadikan siswa yang siap kerja. Jurnal Pengabdian Kepada Masyarakat 
(Abdimas) IKIP Siliwangi, 2(1), 1-10.

Robbins, S. P., \& Coulter, M. (2018). Management (14th ed.). Harlow, England: Pearson Education.

Safarah, A. A., \& Wibowo, U. B. (2018). Program zonasi di sekolah dasar sebagai upaya pemerataan kualitas pendidikan di Indonesia. Lentera Pendidikan, 21(2), 206-213. http://doi.org/10.24252/lp.2018v21n2i6

Salim, F. A., Damajanti, M. N., \& Muljosumarto, C. (2018). Perancangan media edukasi yang dapat mengajarkan nilai moral bagi anak. Jurnal DKV Adiwarna, 1(12), 1-11.

Saputra, S. A., \& Muhari. (2014). Perbedaan motivasi berprestasi siswa ditinjau dari citacita dan status ekonomi orang tua di SMAN 5 Madiun. Character, 2(3), 1-6.

SDN Tomang 11 Pagi. (2018). Kemenkeu Mengajar. Retrieved June 12, 2019, from https://sdntomang11pagi.blogspot.com/2018/10/kemenkeu-mengajar.html

Solikin, A. (2018). Pengeluaran pemerintah dan perkembangan perekonomian (Hukum Wagner) di negara sedang berkembang: Tinjauan sistematis. Info Artha, 2(1), 5364.

Susilo, B. (2016). Penerapan penugasan kelompok untuk meningkatkan kerja sama mahasiswa D1 Pajak Politeknik Keuangan Negara STAN Balai Diklat Keuangan Medan. Info Artha, 4, 143-150.

Wahyuni, S., Rachman, F. H., \& Hendrawan, Y. F. (2016). Pembekalan pemrograman dasar komputer bagi guru TIK dan siswa terpilih di tiga mitra SMA Kabupaten Bangkalan. Jurnal Pengabdian Kepada Masyarakat, 2(1), 111-123. http://doi.org/10.22146/jpkm.22234

Widiyarto, S., Mubasyira, M., \& Ati, A. P. (2018). Penerapan English communication skill pada siswa SMP. Jurnal Pengabdian Kepada Masyarakat (Abdimas) IKIP Siliwangi, 1(2), 75-80. 